\title{
Habitus Poet, Social Capital, and Literary Works
}

\author{
Ekarini Saraswati \\ University of Muhammadiyah Malang, Indonesia \\ ekarinisaraswati12@gmail.com
}

\begin{abstract}
The development of Indonesian literature experienced several periods with its own uniqueness which is influenced by the political situation of each era. The diversity of aesthetic and extra-aesthetic values used by writers indicates the diversity of social backgrounds of writers in terms of social status, education, the surrounding environment and politics that influence their views. The diversity can be seen and observed in the writings put forward by readers, especially ideal readers who provide indepth reviews.The purpose of this research is as follows: (1) to identify readers' receptions of the Indonesian literature of the 70's through books and mass media, (2) to classify readers' receptions of the social capital of Indonesian literature of the 70 's, (3) to describe the influence of social capital owned by writers to their literary works. The theories used to analyze social capital are derived from the thought of Pierre Boudieu. Methodologically, this research uses qualitative approach. Data are collected through observation and documentary techniques. The data that has been collected are analyzed by taking the following steps: data reduction, presentation, and conclusion.Sociologically, the five poets studied in this research come from the upper middle class, most of them are born from the noble classes that has financially allowed them to attend college which at that time was still rare. Such a social background have allowed them have friends and colleage not only on a national scale, but also internationally. Habitus in their family puts them in an academic climate so that writing habit become part of what they often do. Habitus produces lifestyle differences and life practices derived from individual experiences in their social interaction.
\end{abstract}

Keywords:poet, habitus, reader reponse, social capital, poetry

\section{INTRODUCTION}

The development of Indonesian literature experienced several periods with its own characteristics which were influenced by the political situation of the time. Among those periods, the 1970s period is considered important because there were important literary achievement in this period. Rachmat Djoko Pradopo [1] suggests to characterize characteristics of this period in terms of aesthetic and extraesthetic considerations. In the realm of poetry, the features of the dominant esthetic structure of this period is represented in four types of poetry: mantra poetry, imagistic poetry, innocent poetry and ordinary lyric poetry. Mantra poetry has the characteristics of repetition of words, phrases, or sentences of parallelism, combined with hyperbole and enumeration, suggestive typography exploitation, nonsense words of meaningless words, words which are cut off, reversed, and repeated serveal time; the use of regional words; the use of sound associations. The imaginary poetry consists of pictures with paintings or figurative stories (allegory and parables). The innocent poetry uses the technique of innocent disclosure of ideas, with cerebral words, ordinary or innocent sentences.

Extra aesthetic features are also of importance. In the field of poetry, there are attempt to reveal religious inner life with the mystique tedency. There are also demands for human rights: freedom, free life, freedom from oppression; demands of modern life, social criticism of the arbitrariness of the weak and criticism of abuse.

The diversity of aesthetic and extra-aesthetic values used by writers indicates the diversity of socio-cultural backgrounds of writers in terms of social status, education, the surrounding environment and politics that influence their views. The diversity can be seen and observed in the writings put forward by readers, especially ideal readers who provide in-depth reviews. The results of the exploration of the responses of various readers can be seen from the reader's reception of the tendency of the writers to his works.

Observing the various responses of readers from various disciplines would take quite a bit. Therefore, this study is limited to the social capital proposed by Pierre Bourdieu on the work of Indonesian performances. Based on the background of the problems above, we can formulate some research problems: (1) How is the reader's perspective about the influence of the social capital that the writer has on the quality of the literary work of the class of 1970? (2) How is the reader's perspective pattern of the influence of the social capital that the writer has on the quality of literary work of the class of 1970 ?

A text, according to the concept put forward by Lotman (Segers [2]), is characterized by three things: first, a text is explicit, second, it has limit, that is a text has a beginning and an end that distinguishes it from all other structures lacking finite features, third, a text is structured. Teeuw [3] breaks down the characteristics of literary texts by using the term "code". Literary texts have three codes, namely linguistic code, cultural code, and literary code. Teeuw [4] divides it into two rules, namely general rules and specific rules.

Readers are people who accept literary texts. In the process of receiving literary texts, the intended readers differ. Riffatere [5] is one of the experts who gives an idea of the types of readers. He thinks the reader is made up of ideal readers, implicit readers, and real readers.

Continuing theories about the reader will be specifically discussed in the discussion section of the results of data analysis. Discussion of the elements of acceptance begins with Rosenblatt's [6] thought which outlines the main subject matter of transactions between the reader and the text covering the networks of feelings, 
sensations, images, and ideas. By Segers [7] the network in literary transactions is grouped into intellectual and emotional elements. In more detail, Beach [8] classifies the network of literary transactions into five main elements: the textual, experiential, psychological, social, and cultural elements that can be visualized in the following scheme.

The term capital is used by Bourdieu because of its many characteristics that are capable of explaining power relationships. The characteristics are: (1) capital accumulates through investment, (2) capital can be given to others through inheritance, (3) capital may benefit according to the opportunity owned by its owner to operate its placement (Haryatmoko [9]).Bourdieu defines social capital as a collection of potential and / or actual resources associated with the ownership of a network at any given time of the underlying relationship of mutual recognition and mutual recognition. Group membership makes it easy for its members by providing support from collectively owned capital. Social capital is made of social obligations or connections and can be convertible, under certain conditions, into economic capital. Bourdieu states that the content of a person's social capital depends on the size of the network of connections he can mobilize and the capital - economic, cultural, and symbolic load which belongs to the person who is his / her connection. Thus Bourdieu's social capital is rearranged into two elements: first, social relationships, which allow individuals to claim collectively owned resources, and, secondly, the quantity and quality of those resources (Haryatmoko[10] ).

\section{METHOD}

The approach used in this study is a qualitative approach. Qualitative approach is viewed in accordance with the characteristics of research that produces written data from the subject under study. This is in line with the main objective of this research which is to describe and explain the reader's receptions to the Indonesian literary works of the 1970s

The data comes from articles about poetry of Period $70 \mathrm{~s}$. The main data of this research is in the form of written words derived from written documents from literary critics and general readers published in the mass media. The poet of Period 70 taken to study is: WS. Rendra, Toeti Heraty, Sutardji Calzoum Bachri, Sapardi Djoko Damono, andTaufik Ismail,. The subjects of the study are ideal readers, readers who have more literary competence than the general reader, among them literary critics who write their criticism through mass media either newspaper or book

\section{RESULT}

The readers included in this study are the readers who give a review of the work that was born by the poet as well as the reader who reviewed the life of the poet. In terms of textual knowledge, involvement, mental development that they have certainly exceed the ability of the reader in general. In terms of status and cultural diversity based on the background of writers that can be detected for example Seno Gumira Ajidarma which is a short story writer also philosophy lecturer and journalist Syafii Maarif who is a lecturer and chairman of Muhammadiyah organizations. Based on the results of the study there are about 163 readers who discussed these five poets are spread unevenly. Most readers review Rendra, Toeti Heraty Sapardi Djoko Damono,SutardjiCalzoumBachry, and Taufik Ismail, and. The readers of literary critics come from writers published in the mass media as ideal readers.

The Poet's Social Capital

W.S. Rendra is a famous poet who has once been owned by Indonesian nation. He established relationships with various circles from within and outside the country. He was also active in festivals abroad, including The Rotterdam International Poetry Festival (1971 and 1979), The Valmiki International Poetry Festival, New Delhi (1985), Berliner Horizonte Festival, Berlin (1985), The First New York Festival of the Arts (1988), Spoleto Festival, Melbourne, Vagarth World Poetry Festival, Bhopal (1989), World Poetry Festival, Kuala Lumpur (1992), and Tokyo Festival (1995). The command of wide knowledge makes Rendra so concerned with the existence of his country and that he poured it in poems of the form of social criticism.

Toeti Heraty Noerhadi was born from a wellestablished family with his father being a prominent Indonesian building expert Ir Rooseno, making Toety have advantage over his contemporaries. Toeti is a woman poet who is quite well-known in her day. Rarely is the female poet discussed so widely as she. The education she achieved both from home and abroad allows her to have a wide social association nationally and internationally. Toety taught at Philosophy faculty of UI (University of Indonesia) and taught at several other universities also once became a chairwoman of the Jakarta Arts Council (IKJ).

The Poet Sapardi Djoko Damono was born in Solo; he persued his education in English department at UGM and UI, and this made him a professor of UI in the Indonesian language program. His English skills made his knowledge wide by translating foreign books, and foreign readings that he has read made his poetry rich in meaning. One of his best-known friend is Jeihan, a famous painter from Bandung.

Sutardji Calzoum Bachri, the Riau-born poet, was heavily influenced by religious life in Riau so that the poems that were born were mantra. Then he attended the International Writing Program seminar in Iowa City, USA from October 1974 to April 1975. Sutardji also introduced a unique and luring way of poetry reading in Indonesia.

Taufik Ismail was the son of a great religious scholar A. Gafar Ismail. During his university study he was active in publishing his literary writing in various media, serving as a journalist, one of the founders of a wellknown literary magazine Horison (1966), co-founded DKJ (Jakarta Arts Council) and became its leader, Director of TIM, Rector of LPKJ and Manager in Unilever Public Relations. The scholarship recipient of 
AFS International Scholarship, since 1958 has been active in AFS Indonesia, serving as the Chairman of the Board of Trustees of the Intercultural Foundation of Bina Intercultural Foundation, organizer of international exchange for 41 years (since 1957) has sent 1700 students to 15 countries and received 1600 foreign students here. Taufiq was elected to the Board of Trustees AFSIS in New York, 1974-1976.

Habitus, Strategy and Arena

W.S. Rendra accustomed to the life of art in his home so he took art education located in Yogya, Jakarta and in America. Theater performing arts became his choice of life to develop his talents as well as build younger generation to join so that their talent is channeled. The artistry embedded in his soul made his social sensitivity so high that it gave birth to poems of social criticism that occurred in Indonesia. His courage to criticize this has made Rendra hostile to the government so that he had been imprisoned also staging his drama is often banned. But it does not discourage him to sacrifice himself for the benefit of the art world generally in Indonesia so the government finally melts and gives artistic freedom within certain limits.

Toeti Herati has a habit of reading so that unconsciously can give birth to poetry that formerly she did not make part of his ideals. The poems she produced are, according to their readers, are conversational, symbolic and ironic. The contents of the expressed poems mostly tell the story of women. These poetry ability made him a famous poet and served as head of the council art of Jakarta. Also she can travel around the world and read his poems in various events both in Indonesia and abroad. Sapardi Djoko Damono is a poet who lives in the environment of Java society and make the Javanese philosophy to be an inspiration for some of his poems. Awards at home and abroad have been received. According to his readers Sapardi's poems belongs to an imagistic poetry. This poet has advantages in processing the word of everyday use, but has a deep meaning. Sutardji Calzoum Bachri kicked off the Indonesian literary world with his expertise to write different poems to the existing stream by using the mantra as a form of poetry. With a creed and a way of reading poetry other than others, he became the president of the poets. Taufik Ismail, a strong religious life in his family environment made this poet take on the teachings of Islam as the basis for coloring his poems. At the beginning of his appearance his poems contained social criticism in the old-time government, but over time religious poems were also created and collaborated with the music group Bimbo made religious songs to be sung by this music group. With social criticism and religious inspiration poured into his poems, Taufik also made himself involved in popularizing literature to school student to create a literary atmosphere and to increase the literary interest of the students.

\section{CONCLUSION}

From their social background these five poets came from the upper middle class and almost all of them were born from among nobles who were financially able to send them to college which at that time was rare. With such social background they are allowed to get along not only on a national scale, but also internationally. Habitus in their family puts them in an academic setting so that writing habits are a part of what they often do. Habitus produces lifestyle differences and life practices derived from individual experience in interacting. The high power of social and cultural capital makes these five poets a powerful and monumental poet. They are full of confidence to express the life they believe in their poems that often made them clash with the government as well as the literary critics. Habitus and strategy they have make them able to breathe a long breath in the arena of of poetry they enter. Most of them have engaged themselves in the world of poetry for more than ten years, a time span long enough to affect the audience to know them more.

\section{REFERENCES}

[1] Pradopo, Rachmat Djoko, Beberapa Teori Sastra, Metode Kritik, dan Penerapannya, Yogyakarta: Pustaka Pelajar 1995.

[2] Segers, Rien T. Evaluasi Sastra. Terjemahan Suminto A. Sayuti. Yogyakarta: Adicita 2000.

[3] Teeuw, A. Membaca dan Menilai Sastra. Jakarta: Gramedia Pustaka Utama 1991.

[4] Teeuw, A. Sastra dan Ilmu Sastra. Jakarta: Pustaka Jaya.[5] Riffaterre, Michael. 1984. Semiotics of Poetry. Bloomington: Indiana University Press 1984.

[5] Rossenblatt, Louise M. The Reader the Text the Poem: The Transactional Theory by the Literary Work. USA: Southern Illinois University Press 1978.

[6] Segers, Rien T. Evaluasi Sastra. Terjemahan Suminto A. Sayuti. Yogyakarta: Adicita 2000.

[7] Beach. R. A. Teacher's Introduction to Reader Resepsi Theories. Urbana: The National Council of Teacher of English 1993.

[8] Haryatmoko. "Menyingkap Kepalsuan Budaya Penguasa: Landasan Teoretis Gerakan Sosial Menurut Pierre". Dalam Basis, Nomor 11-12, Tahun ke-52, November-Desember 2003. Halaman 4-23.

[9] Haryatmoko. Membongkar Rezim Kepastian: Pemikiran Kritis Post-Strukturalis. Yogyakarta: Kanisius 2016. 